\title{
STUDIES ON THE BIOLUBRICANT PROPERTIES OF MORINGA OLEIFERA SEED OIL: CORRELATING VISCOSITY AND FATTY ACID COMPOSITION
}

\author{
Louis M. Nwokocha*; Toyib B. Aremu
}

Chemistry Department, University of Ibadan, Ibadan, Nigeria

*Corresponding author ; E-mail: 1m.nwokocha@mail.ui.edu.ng

Received: $9^{\text {th }}$ January $2017 \quad$ Revised: $29^{\text {th }}$ June 2017

Accepted: $4^{\text {th }}$ July 2017

\begin{abstract}
This study examined the characteristics of Moringa oleifera seed oil as a biolubricant. The study covered the physicochemical and rheological characteristics of the seed oil. The seed yielded $37.9 \%$ oil with the following physicochemical properties: peroxide value $\left(1.655 \mathrm{meq} \mathrm{kg}^{-1}\right)$, saponification value $\left(154.5 \mathrm{mg} \mathrm{KOH} \mathrm{g}\right.$ ), and acid value $\left(9.724 \mathrm{mg} \mathrm{KOH} \mathrm{g}^{-1}\right)$. The rheological characteristics of $M$. oleifera oil showed the oil was solid at $10.1^{\circ} \mathrm{C}$ and exhibited flow properties typical of vegetable oils in the temperature range 30 to $70^{\circ} \mathrm{C}$ however it exhibited thermal instability at $90^{\circ} \mathrm{C}$ as indicated by the entirely shear thinning properties of the oil attributed to polymerization of the oil to gum. The oil had oleic acid (72.73\%) as the principal fatty acid. The high viscosity of M. oleifera oil (0.06078 Pas, $\left.30^{\circ} \mathrm{C}\right)$ correlates with its high percentage of long chain fatty acids $(\mathrm{C} \geq 16=99.86 \%)$, and the high oleic acid composition indicates a potential for application as a biolubricant.
\end{abstract}

Keywords: Moringa oleifera oil, biolubricant, physicochemical, rheological, fatty acid composition

\section{INTRODUCTION}

There has been growing interest in the use of vegetable oils as lubricants and hydraulic fluids due to the toxicity and environmental issues arising from conventional petroleum-based fluids. Biolubricant is an alternative lubricant different from mineral oil lubricant as it is prepared from non-conventional energy resources and is nontoxic, biodegradable and eco-friendly. Several vegetable oils have been applied as biolubricant and additives including canola, rapeseed, castor and palm (Hsien, 2015). Vegetable oils with high oleic contents are considered to be the best alternative to substitute conventional mineral oil-based lubricating oils and synthetic esters (Singh \& Chhibber, 2013).
Moringa oleifera commonly referred to as "Moringa" is the most widely cultivated species of the genus Moringa, which is the only genus in the family Moringaceae. It is commonly known as the horse-radish or drumstick tree and is native to the subHimalayan region of northwest India. The tree itself is rather slender, with drooping branches and ranges in height from 5-12 m and the fruits (pods) are around $50 \mathrm{~cm}$ long. Fully matured, dry seeds are round or triangular in shape, the kernel surrounded by a light wooded shell with three papery wings (Abdulkarim et al., 2005). It is known as Ben oil tree in English; 'Okwe oyibo' in Igbo, 'Gawara' or 'Habiwal' in Hausa and 'Adagba maloye' or 'Ewe Igbale' in Yoruba, all people of Nigeria. It grows rapidly in most regions and climatic conditions of Nigeria. M. oleifera is an important food 
commodity which has had enormous attention as the 'natural nutrition of the tropics' (Anwar et al., 2007).

There have been several reports in literature on extraction and characterization of $M$. oleifera seed oil. Extraction methods reported included mechanical press (Anwar et al., 2006; Eman \& Muhamad, 2016), solvent extraction (Anwar \& Bhanger, 2003; Abdulkarim et al. 2005; Anwar et al., 2006) and enzymatic extraction (Abdulkarim et al. 2005; Latif et al., 2011), the yield and physicochemical properties of the oil varied with method of extraction. M. oleifera seed oil has been reported to have high degree of unsaturation with oleic acid $(67.8-85 \%)$ as the most prominent fatty acid (Tsaknis et al., 1999; Abdulkarim et al. 2005; Anwar et al., 2006; Nzikou et al., 2009). Studies on the viscosity of the oil as a function of temperature (Nzikou et al., 2009) and melting behavior (Mohammed et al., 2003; Abdulkarim et al. 2005; Nzikou et al., 2009) of the oil have been reported. Abdulkarim et al. (2007) who investigated the frying stability of $M$. oleifera seed oil observed it was more stable than canola oil, soybean oil, and palm oil when used in frying. The rheological properties of $M$. oleifera seed oil have not been well studied especially over a wide range of temperatures. In this work, we studied the rheological properties of $M$. oleifera seed oil using steady shear to investigate the changes in viscosity with temperature and oscillatory shear to determine the changes in mechanical properties with temperature. The rheological characteristics were related to the fatty acid composition of the oil.

\section{MATERIALS AND METHODS}

\section{Extraction of Oil}

Dried pods were collected from $M$. oleifera trees growing on a farmland on the campus of the University of Ibadan. The seeds were removed from the pods, dehulled and the resulting kernels dried in air at ambient temperature. The dried kernels were then blended using an electric blender. The weight of the pulverized flour was measured $(838.87 \mathrm{~g})$, packed in a soxhlet extractor and extracted with hexane for twenty four hours. The $M$. oleifera seed oil was then concentrated by distillation to remove the hexane. The yield was calculated as in Eq. 1.

$$
\text { Yield }(\%)=\frac{\text { Weight of oil extracted }(g)}{\text { Weight of pulverized seed }(g)} X 100
$$

\section{Physicochemical Tests}

\section{Saponification value}

Ethanolic potassium hydroxide $(0.5 \mathrm{~N})$ was pipetted into a conical flask containing $2.0 \mathrm{~g}$ of the oil. The content of the flask was refluxed for $45 \mathrm{~min}$, cooled to room temperature, after which it was titrated with hydrochloric acid $(0.5 \mathrm{~N})$ using phenolphthalein as indicator. A blank was subjected to the same condition. The saponification value was calculated as in Eq. 2. 


$$
\text { Saponification value }(m g \mathrm{KOH} / g)=\frac{\left(V_{b}-V_{s}\right) \times C \times 56.1}{W}
$$

Where $\mathrm{V}_{\mathrm{b}}=$ Titre for the blank $(\mathrm{ml}), \mathrm{V}_{\mathrm{s}}=$ Titre for the sample $(\mathrm{ml}), \mathrm{C}=$ concentration of $\mathrm{HCl}(0.5 \mathrm{~N}), 56.1=$ equivalent weight of $\mathrm{KOH}, \mathrm{W}=$ Weight of oil in gram $(2 \mathrm{~g})$

\section{Peroxide value}

Oil (0.5 g) was added into a boiling tube, glacial acetic acid/chloroform mixture (20 $\mathrm{ml} ; 2: 1$ volume/volume (v/v)) was added, the boiling tube was placed in boiling water for $1 \mathrm{~min}$ after which its content was poured into a conical flask containing $\mathrm{KI}$ solution $(20 \mathrm{ml} ; 5 \%)$. The boiling tube was rinsed twice with distilled water $(25 \mathrm{ml})$ and content added into the conical flask. The liberated iodine was titrated with sodium thiosulphate $(0.002 \mathrm{~N})$ solution until the amber colour lightens when $1 \mathrm{ml}$ of $1 \%$ starch solution was added as indicator. The resulting blue colour was titrated to a colourless end point. A blank was subjected to the same condition. Peroxide value of the oil sample was calculated as in Eq. 3.

$$
\text { Peroxide value }(\text { meq } / \mathrm{kg})=\frac{\left(V_{s}-V_{b}\right) \times \text { normality of titrant } \times 1000 \mathrm{~g} \mathrm{~kg}^{-1}}{W}
$$

Where, $\mathrm{V}_{\mathrm{b}}=$ Titre for blank; $\mathrm{V}_{\mathrm{s}}=$ Titre for sample; $\mathrm{W}=$ Weight of oil in gram.

\section{Acid value}

The number of $\mathrm{mg}$ of potassium hydroxide required to neutralize the free acids in $1 \mathrm{~g}$ of the sample was determined by placing $0.5 \mathrm{~g}$ of the oil in a conical flask containing mixture of ether and ethanol (50 $\mathrm{ml} ; 95 \% \mathrm{v} / \mathrm{v})$. The resulting solution was titrated with $0.1 \mathrm{~N}$ ethanolic potassium hydroxide solution using phenolphthalein as indicator. The acid value was expressed as $\mathrm{mg} \mathrm{KOH} \mathrm{g}{ }^{-1}$ and calculated as in Eq. 4.

$$
\text { Acid value }=\frac{V_{s} \times C \times 56.1}{W}
$$

Where, $\mathrm{V}_{\mathrm{s}}=$ Titre for $\mathrm{KOH}$ used; $\mathrm{C}=$ concentration of $\mathrm{KOH}(0.1 \mathrm{~N}) ; 56.1=$ equivalent weight of $\mathrm{KOH} ; \mathrm{W}=$ Weight of oil in gram $(1 \mathrm{~g})$. 


\section{Rheological Studies}

The rheological measurements were carried out on a Controlled Stress Rheometer (AR 500, TA Instruments Ltd, USA) with cone and plate geometry (40 $\mathrm{mm}, 2^{\circ}$ steel cone and $53 \mu \mathrm{m}$ gap) as reported in Nwokocha \& Olorunsola (2016). The oil was placed on the Peltier plate by means of a spatula spoon, the gap was set and the excess oil trimmed off. The sample was allowed to equilibrate for $30 \mathrm{~s}$ at a given temperature before measurement.

\section{Effect of shear rate and temperature on apparent viscosity}

The effect of shear rate was determined by performing a stepped flow procedure in the shear rate range $1.0 \mathrm{~s}^{-1}$ to $1000 \mathrm{~s}^{-1}$ at different temperatures, $10-90^{\circ} \mathrm{C}$. The flow characteristics were determined according to following shear stress-shear rate rheological models (Eqs. 5-9):

$$
\begin{aligned}
& \text { Herschel-Bulkley }\left(\sigma=\sigma_{Y}+\eta \gamma^{n}\right) \\
& \text { Power Law }\left(\sigma=\eta \gamma^{n}\right) \\
& \text { Bingham }\left(\sigma=\sigma_{Y}+\eta \dot{\gamma}\right) \\
& \text { Newtonian }(\sigma=\eta \dot{\gamma}) \\
& \text { Casson }\left(\sigma^{0.5}=\sigma_{Y}^{0.5}+(\eta \gamma)^{0.5}\right)
\end{aligned}
$$

Where $\sigma=$ shear stress $(\mathrm{Pa}) ; \eta=$ viscosity

$(\mathrm{Pas}) ; \stackrel{\circ}{\gamma}=$ shear rate $\left(\mathrm{s}^{-1}\right) ; \sigma_{Y}=$ yield stress $(\mathrm{Pa})$ and $\mathrm{n}=$ rate index.

\section{Oscillation studies}

Oscillation stress sweep was carried out on the oil at $10^{\circ} \mathrm{C}$ at frequency of $1 \mathrm{~Hz}$ in order to locate the linear viscoelastic region. A temperature sweep was carried out at temperature $70^{\circ} \mathrm{C}$ to $0^{\circ} \mathrm{C}$ at frequency of
$1 \mathrm{~Hz}$ and oscillation stress $0.1 \mathrm{~Pa}$ (oscillation stress in the linear viscoelastic region).

\section{Fatty acid composition}

Fatty acid methyl esters (FAME) were prepared by standard IUPAC method 2.301 (Paquot, 1979). $1 \mathrm{~g}$ oil was weighed into $50 \mathrm{ml}$ round bottom flask and $5 \mathrm{ml}$ of $1 \mathrm{M}$ methanolic $\mathrm{NaOH}$ added. The sample was refluxed at $70^{\circ} \mathrm{C}$ for $20 \mathrm{~min}$, cooled, and hexane and water (10 $\mathrm{ml}$ of each) were added. The mixture was vortex mixed for 15 
min and the upper phase (hexane layer) containing the fatty acid methyl esters was recovered and analyzed by gas chromatography (Varian Chromopack, Model- CP3380, USA). $0.2 \mathrm{ml}$ of the methylated sample was injected into the capillary column (VF-1ms, 30m $0.25 \mathrm{~mm}$ $0.25 \mu \mathrm{m}$; Part number CP8912) in the splitless mode, (injection temperature $260^{\circ} \mathrm{C}$, detector temperature $260^{\circ} \mathrm{C}$ ), the carrier gas was nitrogen (flow rate 30 $\mathrm{ml} / \mathrm{min}$ ) and flowed through the air drier at $571^{\circ} \mathrm{C}$, coolable oven at $100^{\circ} \mathrm{C}$ which increases with time and the Front FID at $260^{\circ} \mathrm{C}$. Fatty acids were identified by comparing with the retention times of FAME with a standard 37 component FAME mixture (Resket). The components eluting from the column were detected by flame ionization detector whose signal output was captured and recorded in computer with Totalchrom software data system. Three replicate GC analyses were performed and the result was expressed as as percentage of the sum of all fatty acids in the sample as indicated in Eq. 10.

$$
\% \text { Fattyacid }=\left[\frac{\text { Fattyacid peak area }}{\sum \text { total fattyacid peak areas }}\right]
$$

\section{RESULTS AND DISCUSSION}

\section{Physicochemical Properties}

The physicochemical properties of M. oleifera oil are presented in Table 1. The yield of $M$. oleifera seed oil was $37.9 \%$ which makes the oil economical for commercial extraction. The yield is in the range of values reported in literature (Anwar et al., 2005; Abdulkarim et al. 2005). 
Table 1. Physicochemical properties of Moringa oleifera seed oil

\begin{tabular}{lc}
\hline Parameters & Characteristics \\
\hline Colour & Light golden yellow \\
Yield (\%) & 37.9 \\
State .at room temperature & Liquid \\
Acid value (mg KOH g $\left.{ }^{-1}\right)$ & $9.724 \pm 0.56$ \\
Saponification value $\left(\mathrm{mg} \mathrm{KOH} \mathrm{g}^{-1}\right)$ & $154.5 \pm 0.81$ \\
Peroxide value $\left(\mathrm{meq} \mathrm{kg}^{-1}\right)$ & $1.655 \pm 0.01$ \\
\hline
\end{tabular}

Mean \pm standard deviation $(n=3)$

The acid value obtained for the $M$. oleifera seed oil $(9.724 \pm 0.56 \mathrm{mg} \mathrm{KOH} / \mathrm{g})$ is higher than $(3.8 \pm 0.28 \mathrm{mg} \mathrm{KOH} / \mathrm{g})$ reported by Ogbunugafor et al. (2011). The oil is less corrosive than pawpaw (47.12 $\mathrm{mg} \mathrm{KOH} / \mathrm{g}$ ) and orange (51.4 mg $\mathrm{KOH} / \mathrm{g}$ ) seed oils (Audu et al., 2013). The acid value is outside the range $(0.00-3.00 \mathrm{mg} \mathrm{KOH} / \mathrm{g})$ recommended for cooking oil (Oderinde et al., 2009).

The peroxide assay is a predominant test for oxidative rancidity in oils and fats. A high peroxide value for any oil shows that the oil has less resistance to lipolytic hydrolysis and oxidation. The peroxide value of $M$. oleifera seed oil $(1.655 \pm 0.01$ meq $\mathrm{kg}^{-1}$ ) is low and indicates less susceptibility to oxidation (Ezeh et al.,
2012). The saponification value $(154.5 \mathrm{mg}$ $\mathrm{KOH} / \mathrm{g}$ ) is lower than $164.09-171.9 \mathrm{mg}$ $\mathrm{KOH} / \mathrm{g}$ (Ogbunugafor et al., 2011; Orhevba et al., 2013) but higher than $143.76 \mathrm{mg}$ $\mathrm{KOH} / \mathrm{g}$ reported for African pear oil. The oil could be good for soap making. Saponification value is inversely proportional to the mean molecular weight of the glycerides in the oil (Ikhuoria \& Maliki, 2007).

\section{Rheological Properties}

Figure 1 shows the viscosity shear rate flow curves of $M$. oleifera seed oil at different temperatures while the flow characteristics obtained from the curves by fitting to different shear stress-shear rate models are presented in Table 2. 


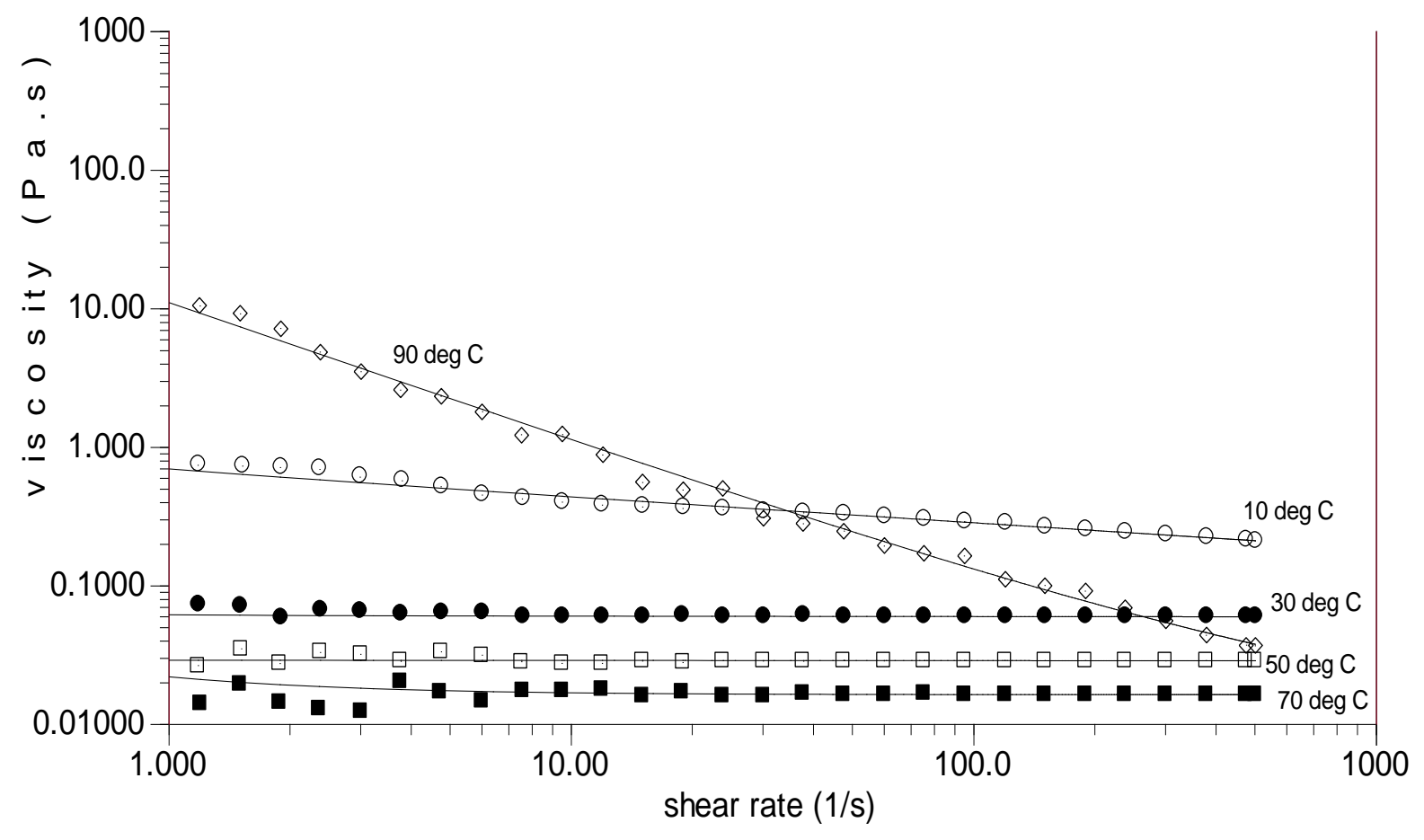

Figure 1. Viscosity- shear rate curves of Moringa oleifera oil at different temperatures fitted to several rheological models 
Table 2. Parameters of the flow curves of Moringa oleifera seed oil fitted to various shear stressshear rate rheological models

\begin{tabular}{lllllll}
\hline Model & Parameter & $\mathbf{1 0}^{\mathbf{0}} \mathbf{C}$ & $\mathbf{3 0}^{\mathbf{0}} \mathbf{C}$ & $\mathbf{5 0}^{\mathbf{0}} \mathbf{C}$ & $\mathbf{7 0}^{\mathbf{0}} \mathbf{C}$ & $\mathbf{9 0}^{\mathbf{0}} \mathbf{C}$ \\
\hline Herschel- & $\sigma_{\mathrm{y}}$ & 0.03131 & $1.198 \mathrm{E}-3$ & $4.191 \mathrm{E}-3$ & $5.757 \mathrm{E}-3$ & 11.05 \\
Bulkley & $\eta$ & 0.6682 & 0.06078 & 0.02894 & 0.01634 & 0.05649 \\
& $\mathrm{n}$ & 0.8153 & 0.9977 & 0.9995 & 1.001 & 0.7956 \\
& $\mathrm{~s} . \mathrm{e}$ & 2.498 & 0.430597 & 0.8651 & 1.182 & 78.9488 \\
Power law & $\eta$ & 0.6718 & 0.06082 & 0.02911 & 0.01659 & 11.37 \\
& $\mathrm{n}$ & 0.8145 & 0.9976 & 0.9986 & 0.9983 & 0.04627 \\
& $\mathrm{~s} . \mathrm{e}$ & 2.526 & 0.439333 & 0.8070 & 1.285 & 107.203 \\
Bingham & $\sigma_{\mathrm{y}}$ & 1.945 & 0.01011 & $1.839 \mathrm{E}-4$ & $5.483 \mathrm{E}-3$ & 11.22 \\
& $\eta$ & 0.2194 & 0.05995 & 0.02887 & 0.01641 & 0.01642 \\
& $\mathrm{~s} . \mathrm{e}$ & 24.53 & 0.467213 & 0.8290 & 1.184 & 80.2825 \\
& & & & & \\
Newtonian & $\eta$ & 0.2258 & 0.05995 & 0.02887 & 0.01641 & 0.05302 \\
& $\mathrm{~s} . \mathrm{e}$ & 29.72 & 0.562186 & 0.8291 & 1.336 & 557.709 \\
& & & & & & \\
Casson & $\sigma_{\mathrm{y}}$ & 0.8723 & $8.185 \mathrm{E}-4$ & $5.675 \mathrm{E}-7$ & $3.168 \mathrm{E}-5$ & 10.68 \\
& $\eta$ & 0.1801 & 0.05919 & 0.02888 & $3.433 \mathrm{E}-4$ & $1.958 \mathrm{E}-3$ \\
& s.e & 12.39 & 1.01729 & 0.8489 & 280.7 & 82.2773 \\
\hline
\end{tabular}

$\sigma_{\mathrm{y}}=$ shear stress $(\mathrm{Pa}), \eta=$ viscosity $(\mathrm{Pas}), \mathrm{n}=$ rate index (dimensionless), s.e $=$ standard error.

The flow curve at $10^{\circ} \mathrm{C}$ and $90^{\circ} \mathrm{C}$ were different from the other curves as they were essentially shear thinning or NonNewtonian flow. From Table 2, it can be seen that there was a decrease in viscosity as temperature increased from $10^{\circ} \mathrm{C}$ to $70^{\circ} \mathrm{C}$. This is because an increase in temperature results in an addition of thermal energy to a system which will increase the vibrational energy of the molecules and thereby weaken the inter- and intra-molecular associations resulting in ready flow. This is in agreement with results observed with other oils (Stanciu, 2012; Nwokocha \& Olorunsola, 2016). However the change in viscosity at $90^{\circ} \mathrm{C}$ was unusual, instead of viscosity decreasing, it rather increased. The viscosity at $10^{\circ} \mathrm{C}$ was shear thinning throughout the shear rate range this is attributed to low thermal energy of the oil molecules resulting in increased intermolecular attraction and the change of state to solid- a soft solid. These associations were broken down under shear action. This can also be seen from the rate index (n) of 0.8153. It can be seen that as temperature increased up to $70^{\circ} \mathrm{C}$, the rate index (n) approached unity (Newtonian). The flow profile of the oil at $90^{\circ} \mathrm{C}$ is one of a strongly shear thinning fluid $(n=0.7956)$ completely distinct from a near Newtonian behavior observed at 30 to $70^{\circ} \mathrm{C}$. This transformation is indicative of thermal instability at $90^{\circ} \mathrm{C}$. The transformation is attributed to thermally 
induced polymerization of unsaturated carbons in the oil to a resinous mass. The reactivity and polymerization of unsaturated carbon in oil forming long chains of molecules has being remarked (Srivastava \& Sahai, 2013). All the shear stress-shear rate rheological models failed to describe the flow characteristics of $M$. oleifera oil at $90^{\circ} \mathrm{C}$. The Casson model also failed to describe the rheological properties of the oil at $70^{\circ} \mathrm{C}$ as seen from the high values of the standard errors of estimates which are more than 20 . The high yield stress $(11.05 \mathrm{~Pa})$ and the shear thinning characteristic indicated by the low value of the rate index (0.7956), support the observed transformation of the oil. The instability of the M. oleifera oil at $90^{\circ} \mathrm{C}$ is a limitation to its suitability as biolubricant at temperatures $\geq 90^{\circ} \mathrm{C}$. Nzikou et al., (2009) studying the effect of temperature $\left(5-45^{\circ} \mathrm{C}\right)$ on the viscosity of $M$. oleifera seed oil observed a similar decrease in viscosity as temperature increased, and at $30^{\circ} \mathrm{C}$, the viscosity of the oil was 0.04527 Pas for Blye and Dyer (chloroform) extraction method and 0.04815 Pas for soxhlet (petroleum ether) extraction method.

Figure 2 shows the oscillation stress sweep used to obtain the linear viscoelastic region. Oscillation stress of $0.1 \mathrm{~Pa}$ which fell within the linear viscoelastic region- a region where the material properties of the oil were not affected by the applied stress was used for temperature sweep. 


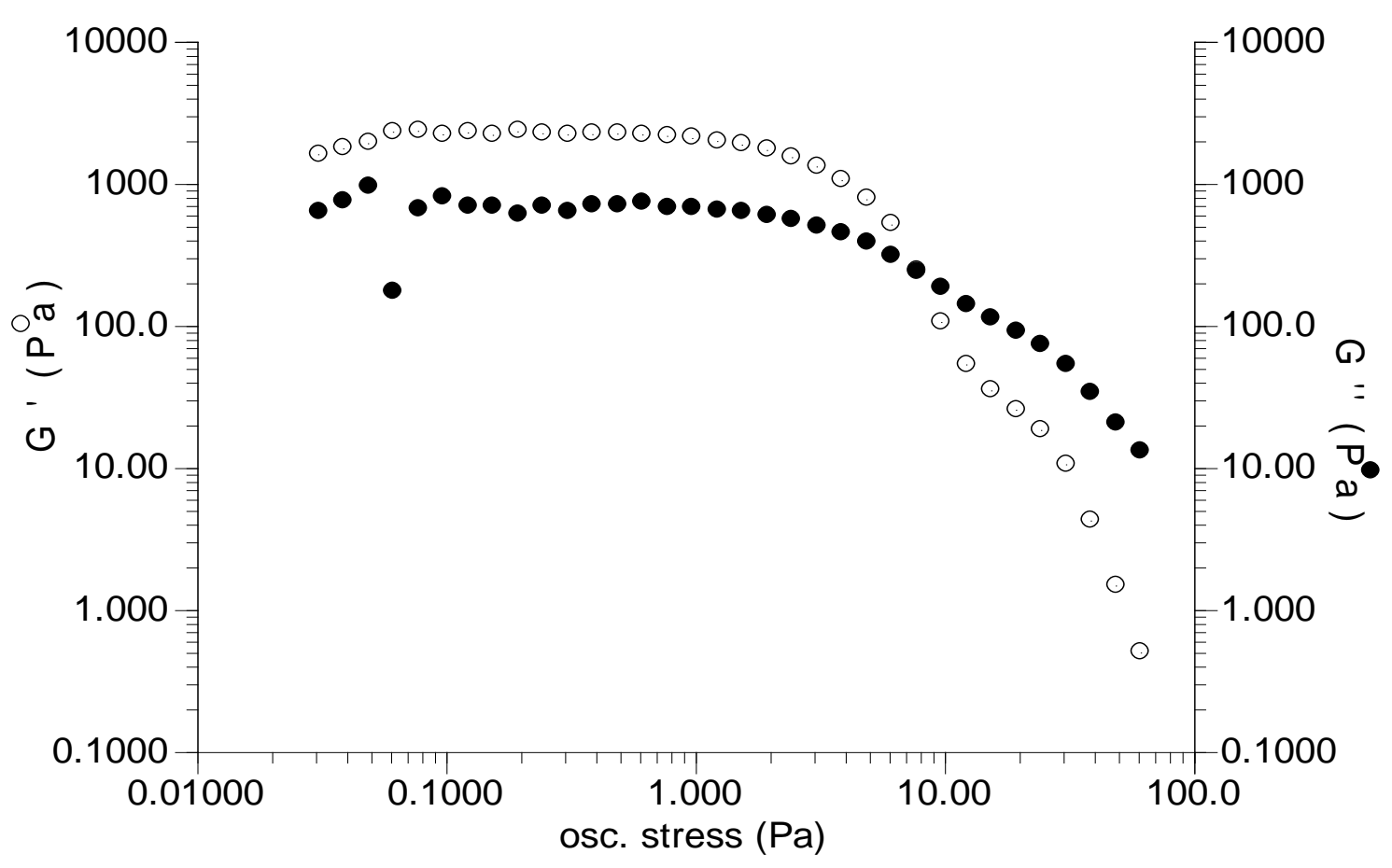

Figure 2. Elastic modulus $\left(\mathrm{G}^{\prime}\right)$, loss modulus $\left(\mathrm{G}^{\prime \prime}\right)$ versus oscillation stress at $1 \mathrm{~Hz}, 10^{\circ} \mathrm{C}$. 


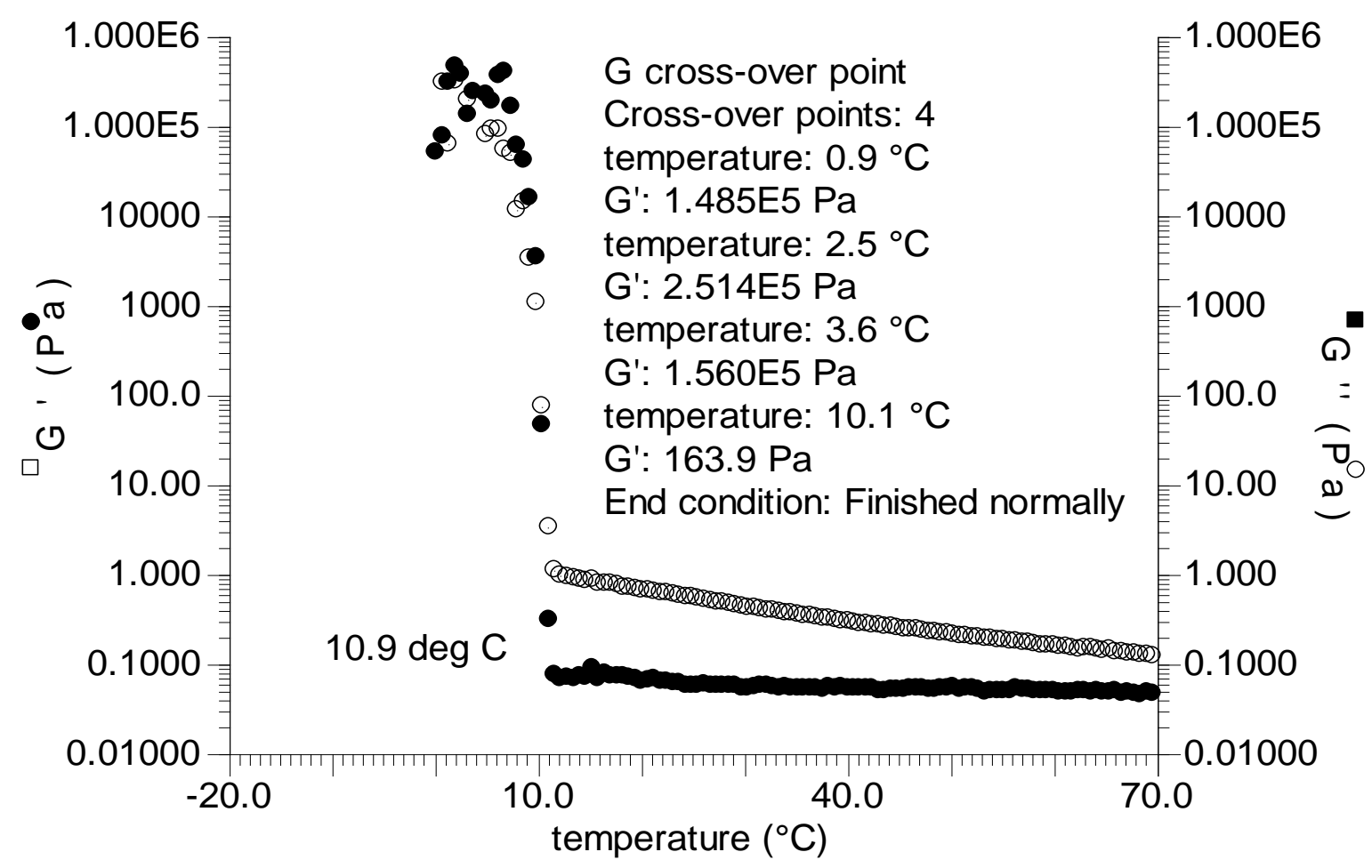

Figure 3. Temperature sweep showing elastic modulus $\left(\mathrm{G}^{\prime}\right)$, loss modulus $\left(\mathrm{G}^{\prime \prime}\right)$ versus temperature at frequency of $1 \mathrm{~Hz}$, oscillation stress of $0.1 \mathrm{~Pa}$

Figure 3 shows the elastic modulus $\left(\mathrm{G}^{\prime}\right)$, loss modulus $\left(\mathrm{G}^{\prime \prime}\right)$ versus temperature for $M$. oleifera oil at frequency of $1 \mathrm{~Hz}$ and oscillation stress of $0.1 \mathrm{~Pa}$. As temperature decreased from $70^{\circ} \mathrm{C}$, the distance between $\mathrm{G}^{\prime}$ and $\mathrm{G}^{\prime \prime}$ became wider but $\mathrm{G}^{\prime \prime}>\mathrm{G}^{\prime}$ indicating the viscous nature of the oil. At $10.9^{\circ} \mathrm{C}$ there was a sharp change in the values of the moduli with the separation becoming narrower indicating increased association between oil molecules and an approach to transition. However a crossover occurred at $10.1^{\circ} \mathrm{C}\left(\mathrm{G}^{\prime}=\mathrm{G}^{\prime \prime}=163.9 \mathrm{~Pa}\right)$. Thus $10.1^{\circ} \mathrm{C}$ could be taken as the melting point of the oil. Above $10.1^{\circ} \mathrm{C}$ the oil was liquid-like $\left(\mathrm{G}^{\prime \prime}>\mathrm{G}^{\prime}\right)$ but below this temperature the oil was solid-like $\left(\mathrm{G}^{\prime}>\mathrm{G}^{\prime \prime}\right)$. This explains the flow characteristics of $M$. oleifera oil at $10^{\circ} \mathrm{C}$ (soft solid) in which the oil exhibited a shear thinning property throughout. Lower temperature hardening transitions were also observed in the oil but these occurred after change of state from liquid to solid. The melting temperature of M. oleifera seed oil has been studied using other instrumentations: differential scanning calorimetry (DSC) (Mohammed et al., 2003; Abdulkarim et al., 2005; Nzikou et al., 2009), WRR melting point apparatus (Ogbunugafor et al., 2011). Mohammed et al., (2003) reported a melting point of $20.5^{\circ} \mathrm{C}$ for solvent extracted oil while Abdulkarim et al., (2005) reported $19.0^{\circ} \mathrm{C}$ and $18.9^{\circ} \mathrm{C}$ for solvent- and enzymeextracted oils, respectively. In another study, Ogbunugafor et al., (2011) obtained a 
melting point of $28^{\circ} \mathrm{C}$ for the oil. In a study by Nzikou et al., (2009) using DSC, they observed three different melting transitions which they attributed to the existence of different crystal forms in the oil they associated this to different degrees of saturation/unsaturation of the fatty acids. They also observed that the melting point depended on the method of extraction and scan speed in the DSC. At a scan rate $10^{\circ} \mathrm{C} / \mathrm{min}$ over a range $\left(-50^{\circ}\right.$ to $\left.50^{\circ} \mathrm{C}\right)$ they obtained the following melting transition temperatures: (petroleum ether extracted: 10.64 $\left.{ }^{\circ} \mathrm{C}, \quad-6.71^{\circ} \mathrm{C}, \quad-31.54^{\circ} \mathrm{C}\right) \quad$ and (chloroform extracted: $11.13^{\circ} \mathrm{C},-6.23^{\circ} \mathrm{C}$, $33.52^{\circ} \mathrm{C}$ ). The first transition in a cooling cycle for solvent extracted oil $\left(10.64^{\circ} \mathrm{C}\right)$ is close to $10.1^{\circ} \mathrm{C}$ which we obtained by rheometry.

\section{Fatty acid Composition}

The fatty acid profile of $M$. oleifera seed oil is shown in Table 3.

The major fatty acids in order of abundance were oleic acid (72.73\%), palmitic acid $(7.25 \%)$, linoleic acid $(5.75 \%)$ and stearic acid (4.63\%). Oleic acid is the principal fatty acid in M.oleifera seed oil and this agrees with values $(67.8-85 \%)$ in the literature (Tsaknis et al., 1999; Abdulkarim et al., 2005; Anwar et al., 2006)

Table 3. Fatty acids present in Moringa oleifera seed oil

$\begin{array}{llll}\text { Peak Name } & \text { Fatty Acid Present } & \text { Retention Time } & \text { Fatty acid (\%) } \\ \text { C14:0 } & \text { Myristic acid } & 37.228 & 0.14 \\ \text { C16:0 } & \text { Palmitic acid } & 41.005 & 7.25 \\ \text { C16:1 } & \text { Palmitoleic acid } & 41.757 & 1.50 \\ \text { C18:0 } & \text { Stearic acid } & 44.925 & 4.63 \\ \text { C18:1n9c } & \text { Oleic acid } & 45.672 & 72.73 \\ \text { C18:2n6c } & \text { Linoleic acid } & 45.761 & 5.75 \\ \text { C18:3n6 } & \text { V-Linolenic acid } & 48.846 & 0.51 \\ \text { C20:0 } & \text { Arachidic acid } & 49.327 & 2.26 \\ \text { C18:3n3 } & \text { Linolenic acid } & 50.235 & 1.46 \\ \text { C20:4n6 } & \text { Arachidonic acid } & 55.311 & 3.47 \\ \text { C24:0 } & \text { Lignoceric acid } & 63.86 & 0.30\end{array}$

$\begin{array}{ll}\text { Recovery } & 100\end{array}$ 
Table 4. Classification of the fatty acids in Moringa oleifera seed oil

Saturated Fatty Acid, SFA (\%)

Unsaturated Fatty Acid, UFA (\%)

Monounsaturated Fatty Acid, MUFA (\%)

Polyunsaturated Fatty Acid, PUFA (n $\geq 2)(\%)$

Fatty Acid $(\mathrm{C} \geq 16)(\%)$

99.86

Table 4 shows the classification of the fatty acids in $M$. oleifera seed oil. The oil contained $85.42 \%$ unsaturated fatty acids (UFA) of which $74.23 \%$ were monounsaturated (MUFA). M. oleifera seed oil contained principally long chain fatty acids with $\mathrm{C} \geq 16$ of $99.86 \%$. The thermal instability of the $M$. oleifera oil at high temperatures has been attributed to the thermal polymerization of the UFA.

\section{Biolubricant Characteristics}

The biolubricancy of a vegetable oil is determined by its viscosity and the type of fatty acids it contains. The ability of the vegetable oil to create and maintain a lubrication film between two moving metal surfaces is much dependent on the viscosity of the oil itself (Kittiwake).

The $M$. oleifera oil had a viscosity of $0.06078 \mathrm{Pas}$ at $30^{\circ} \mathrm{C}$. This is in the range of viscosities of vegetable oils like canola, rapeseed and sunflower applied as biolubricants (Fasina \& Colley, 2008; Diamante \& Lan, 2014). This viscosity is higher than $4.5 \times 10^{-2}$ Pas reported for $D$. microcarpum $(\mathrm{C} \geq 15=79.41 \%), 5.6 \times 10^{-2}$ Pas for $A$. africana $(\mathrm{C} \geq 15=96 \%)$
(Nwokocha \& Olorunsola, 2016). It has been reported that vegetable oils with high oleic contents are best oils as biolubricant (Singh \& Chhibber, 2013). The oleic acid content of $M$. oleifera seed oil $(72.73 \%)$ is high indicating a potential for application as a biolubricant. $M$. oleifera oil is a triacylglycerol with long fatty acid chains and polar groups which make it amphiphilic in character, and therefore allows it to be an excellent choice as lubricant and functional fluid. The polar ester groups in the oils possess more sites to react and adsorb with metal surfaces to provide boundary lubrication effects (Hsien, 2015). Boyde \& Randley (2013) have stated that these triacylglycerol molecules in vegetable oils orient themselves with the polar end at the solid surface making a closed packed monomolecular or multimolecular layer resulting in a surface film that provides desirable qualities in a lubricant. Another advantage of long chain triacylglycerol is the very low volatility due to the high molecular weight of the triglyceride molecule and excellent viscosity properties.

From the rheological characteristics of $M$. oleifera oil, it can be seen it has limitations in application as biolubricant at low 
temperatures $\left(\sim 10^{\circ} \mathrm{C}\right)$ as the oil solidifies and forms fatty crystals and therefore would not form continuous film on metal surface. Also at temperatures $\sim 90^{\circ} \mathrm{C}$ the oil also fails because it polymerizes to a resinous mass. For environmental safety, $M$. oleifera oil can be used as biolubricant in machinery that loses oil directly into the environment during use like Chain saw, and in machinery used in any sensitive areas, such as in or near water (Hsien, 2015).

\section{CONCLUSION}

Moringa oleifera gave a high oil yield (37.9\%), a quantity high for commercial exploitation. The oil has a melting point of $10.1^{\circ} \mathrm{C}$ and is essentially Newtonian at $30-70^{\circ} \mathrm{C}$ with viscosity decreasing from $0.06078-0.01634$ Pas with increasing temperature. It exhibited thermal instability at $90^{\circ} \mathrm{C}$ polymerizing to gel-like material with strong shear thinning property. The major fatty acid in $M$. oleifera oil was oleic acid. The characteristics of the oil make it a candidate for biolubricant.

\section{ACKNOWLEDGEMENT}

One of the authors, L.M. Nwokocha, thanks the Director, CWSP, Glyndwr University, Wrexham, UK, for the use of the Controlled Stress Rheometer.

\section{REFERENCES}

Abdulkarim, S. M., Long, K., Lai, O. M., Muhammad, S. K. S. \& Ghazali, H. M. (2005). Some physicochemical properties of Moringa oleifera seed oil extracted using solvent and aqueous enzymatic methods. Food Chemistry 93: 253-263.

Abdulkarim, S. M., Long, K., Lai, O. M., Muhammad, S. K. S. \& Ghazali, H. M. (2007). Frying quality and stability of high-oleic Moringa oleifera seed oil in comparison with other vegetable oils. Food Chemistry 105(4): 13821389.

Anwar, F., Ashraf, M. \& Bhanger, M.I. (2005). Interprovenance variation in the composition of Moringa oleifera oil seeds from Pakistan. Journal of American Oil Chemists Society 82: 45-51.

Anwar, F. \& Bhanger, M.I. (2003). Analytical characterization of Moringa oleifera seed oil grown in temperate regions of Pakistan. Journal of Agricultural and Food Chemistry 51(22): 6558-63.

Anwar, F., Latif, S., Ashrat, M. \& Gilani, A.H. (2007). Moringa oleifera: A food plant with multiple medicinal uses. Phytotherapy Research 21: 17-25.

Anwar, F., Zafar, S.N. \& Rashid, U. (2006). Characterization of Moringa oleifera seed oil from drought and irrigated regions of Punjab, Pakistan. GRASAS Y ACEITES 57 (2): 160168. 
Audu, T. O. K., Aluyor, E. O., Egualeona, S. \& Momoh, S. S. (2013). Extraction and characterization of Chrysophyllum albidum and Luffa cylindrica seed oils. Petroleum Technology Journal: An International Journal 3(1): 1-7

Boyde, S. \& Randley, S.J. (2013). Chapter 3 Esters. Synthetics, mineral oils and biobased lubricants: Chemistry and Technology. Rudnick, L.R. (Ed.), (pp 62-63), $2^{\text {nd }}$ Edition, CRC Press, Taylor and Francis, Oxford, United Kingdom.

Diamante, L.M. \& Lan, T. (2014). Absolute viscosities of vegetable oils at different temperatures and shear rate range of 64.5 to $4835 \mathrm{~s}^{-1}$. Journal of Food Processing 2014: 1-6.

Eman, N.A. \& Muhamad, K.N.S. (2016). Comparison of Moringa oleifera seeds oil characterization produced chemically and mechanically. International Conference on Chemical Engineering and Bioprocess Engineering IOP Publishing IOP Conf. Series: Earth and Environmental Science 36: 012063

Ezeh, I.E., Umoren, S.A., Essien, E.E. \& Udoh, A.P. (2012). Studies on the utilization of Hura crepitans L. seed oil in the preparation of alkyd resin. Industrial Crops and Products 36: 94-99.
Fasina, O.O. \& Colley, Z. (2008). Viscosity and specific heat of vegetable oils as a function of temperature: $35^{\circ} \mathrm{C}$ to $180^{\circ} \mathrm{C}$. International Journal of Food Properties 11: 738-746.

Hsien, L.Y. W. (2015). Chapter 2 Utilization of vegetable oil as bio-lubricant and additive toward green lubrication in machines. Springer Briefs in Green Chemistry for Sustainability, (pp1-17), Springer Publishing, New York, USA.

Ikhuoria, E.U. \& Maliki, M. (2007). Characterization of avocardo pea (Persea americana) and African pea (Dicryodes edulis) extracts. African Journal of Biotechnology 6(7): 950952.

Kittiwake, P. Viscosity: A lubricant's most important characteristic. Parker Kittiwake.

www.kittiwake.com/sites/default/files/ 2\%20-\%20Viscosity\%20Dec12_0.pdf (Sourced 18-8-2016).

Latif, S., Anwar, F., Hussain, A. I. \& Shahid, M. (2011), Aqueous enzymatic process for oil and protein extraction from Moringa oleifera seed. European Journal of Lipid Science and Technology 113: 1012-1018.

Mohammed, A.S., Lai, O.M., Muhammad, S.K.S., Long, K. \& Ghazali, H.M. (2003). Moringa oleifera, Potentially a New Source of oleic acid-type oil for Malaysia. In Investing in Innovation 2003, Vol 3: Bioscience and Biotechnology, ed. Mohd. Ali Hassan et al., pp 137-140. Universiti 
Putra Malaysia Press, Serdang Press, Selangor, Malaysia.

Nzikou, J.M., Matos, L., Moussounga, J.E., Ndangu, C.B., Kimbonguila, A., Silou, T., Linder, M., \& Desobry, S. (2009). Characterization of Moringa oleifera seed oil variety Congo-Brazzaviile. Journal of Food Technology 7(3): 5965.

Nwokocha, L.M. \& Olorunsola, F.T. (2016). Rheological characteristics and fatty acid compositions of Afzelia africana and Detarium microcarpum seed oils. Journal of Cereals and Oilseeds 7(4): 34-43.

Oderinde, R. A., Ajayi, I. A. \& Adewuyi, A. (2009). Characterization of seed and seed oil of Hura crepitan and the kinetics of degradation of the oil during heating. Electronic Journal of Environmental Agriculture and Food Chemistry 8(3): 201-208.

Ogbunugafor, H. A., Eneh, F. U., Ozumba, A.N., Igwo-Ezikpe, M.N., Okpuzor, J., Igwilo, I.O., Adenekan, S.O. \& Onyekwelu, O.A. (2011). Physicochemical and antioxidant properties of Moringa oleifera seed oil. Pakistan Journal of Nutrition 10 (5): 409-414.

Orhevba, B. A., Sunmonu, M. O. \& Iwunze, H. I. (2013). Extraction and characterization of Moringa oleifera seed oil. Research and Reviews: Journal of Food and Dairy Technology, 1(1): 22-27

Paquot, C. (1979). IUPAC. Standard methods for the analysis of oils, fats and derivatives. C. Paquot (Ed.), $6^{\text {th }}$ ed., (pp 96-98), Pergamon Press, Oxford, United Kingdom.

Singh, C.P. \& Chhibber, V.K. (2013). Chemical modification in Karanja oil for biolubricant industrial applications. Journal of Drug Delivery and Therapeutics 3: 117-122.

Srivastava, A. \& Sahai, P. (2013). Vegetable oils as lube basestocks: A review. African Journal of Biotechnology12(9): 880-891.

Stanciu, I. (2012). A new viscositytemperature relationship for vegetable oil. Journal of Petroleum Technology and Alternative Fuels 3(2): 19-23.

Tsaknis, J., Lalas, S., Gergis, V., Dourtoglou, V. \& Spiliotris, V. (1999). Characterization of Moringa oleifera Mbololo variety seed oil of Kenya. Journal of Food and Agricultural Chemistry 47(11): 44954499. 